\title{
Effects of Public Procurement Disposal Act (2005) on Transparency and Accountability on Management of Public Finance: A Case of Public Secondary Schools in Imenti North District
}

\author{
Zipporah Mukoruru \\ School of Human Resource Development, Jomo Kenyatta University \\ P.O. Box 60200 Meru - Kenya \\ E-mail: zmukoruru@yahoo.com \\ Dr Mike A. Iravo \\ School of Human Resource Development, Jomo Kenyatta University \\ P.O. Box 62000 NAIROBI - Kenya \\ E-mail: zmukoruru@yahoo.com
}

\begin{abstract}
Public procurement has a real impact on everyday lives as the creation of both social and economic infrastructure like roads, schools, hospitals and provisions for drinking water and sanitation are but examples of government investment in public sector. The ultimate goal of public procurement is to satisfy the public interest in this sense of good procurement that should satisfy the needs of the people, should be fair to business, should save and avoid wastage of public funds. Therefore this study intention was to establish the effects of Public Procurement Disposal Act (2005) on transparency and accountability on management of public finance: It was guided by the following objectives; to examine the causes of the delay in procurement activities and their effects; to examine the extent to which the Public Procurement and Disposal Act achieves transparency in the use of state resources, to assess the effects of Public Procurement and Disposal Act on expenditure control and to determine the effects of Public Procurement Disposal Act on fairness and competition. This study adopted descriptive research design and the sample was selected using simple random sampling to ensure representativeness. Data was collected from 86 respondents drawn from 43 public secondary schools in Imenti North District in Meru County and this comprised of two members from tendering committee from each school. Imenti North District was selected since it has the highest number of public Secondary schools in Meru County. Data was collected through semistructured questionnaire. After the collection of data it was analyzed using SPSS and thereafter presented using frequency tables and percentages. The study revealed $(67.9 \%)$ that procurement activities and procedures were not transparent in that decisions on procurement activities did not follow the rules and regulations of the Act and these decisions were not available and accessible to the public.
\end{abstract}

Keywords: Accountability Procurement, Financial Management, Transparency, Procurement Planning, Disclosure

\section{Background to the Study}

Procurement includes all activities required in order to obtain the product from the supplier and get it to the place where it is actually needed. It encompasses the purchasing function,

Stores, traffic and transportation, incoming inspection and quality control and assurance (Farmer and Weele, 2000). Procurement, according to Wind and Thomas (2001), is as old as

Organizations but it has evolved over time. It developed from the need of organizations to acquire those goods and services that they could not produce but needed in their operations. Initially, the focus of contracting was typically on minimizing costs to the procurement entity rather than on delivering specific service quality outcomes. With time procurement has evolved to include new aspects like strategic sourcing, e-procurement and performance-based service contracting.

To achieve Value for Money (VFM) for the taxpayer, effectively managed procurements, properly planned and executed are essential. Public procurement is the process whereby public sector organizations acquire goods, services and works from third parties. It also includes money spent by public sector to provide key services directly to citizens in areas such as welfare, education, social care and health. Such services are delivered through procurement mechanisms with a formal competitive process. Effective public procurement is essential for good public services and good governance. The public sector in the UK for example spends well over $£ 150$ billion a year on the goods and services necessary to deliver public services (European Commission, 2007).

The public procurement system in Kenya has evolved from a crude system with no regulations to an orderly legally regulated procurement system. The Government's procurement system was originally contained in the Supplies Manual of 1978, which was supplemented by circulars that were issued from time to time by the 
Treasury. The Director of Government Supply Services under the ministry of finance was responsible for ensuring the proper observance of the provisions of the manual. The manual created various tender boards for adjudication of tenders and their awards and subsequent follow-up. However, these boards were not so effective (Aketch, 2005 as quoted by Kipchilat, 2006).

Kipchilat (2006) notes that public procurement is different from private procurement because in public procurement the economic results must be measured against more complex and long-term criteria. Furthermore, public procurement must be transacted with other considerations in mind, besides the economy. These considerations include accountability, non-discrimination among potential suppliers and respect for international obligations. Baily et al (1998) note that public purchases are accountable to the public whose money is spent, including disappointed tenderers and potential suppliers. As such they must produce procedures and practices which will stand up to scrutiny during either government audits or challenge through the courts of any purchasing decision that has been made un-procedurally. The primary purpose of public accountability is to prevent abuses of taxpayer's money. Transparency and Accountability

Greuning (2005) also asserts that transparency refers to the principle of creating an environment where information on existing conditions, decisions and actions are made accessible, visible and understandable to all individual participants. Transparency means that the same rules apply to all suppliers of goods, works and services and that these rules are publicized as the basis of procurement decisions prior to their use. Transparency enables the creation of open, fair and transparent procedures. It promotes inward investment and competitiveness as the public sector is seen as a responsible business partner. According to Osafo-Marfo (2003), transparency means decisions taken and their enforcement is done in a manner that follows rules and regulations. It also means that information is freely available and directly accessible to those who will be affected by such decisions and their enforcement. It also means that enough information is provided and that it is provided in easily understandable forms and media. In the context of this study, it means that information concerning procurement must be known and accessible to all who participate in procurement process.

The Kenya Public Procurement Disposal Act (2005) requires that all public officials and practitioners of procurement shall be held accountable and responsible for their actions; all suppliers, contractors and consultants will be treated fairly and given equal opportunity to obtain contracts with the Government. Procurement shall be done in the most efficient manner, upholding the principles of value for money, transparency and fairness and funds will be used solely for the purposes for which they have been entrusted. Appropriate procedures of the government or the Development Partners are applied; all transactions are properly authorized and fully supported by written records; value for money can be demonstrated by comparison with market rates; and an appropriate Code of Ethics is followed by all staff involved in the procurement process. For Public Procurement Act to achieve transparency, it needs to follow all the rules and regulations in the public procurement. The government of Kenya put in place provisions to ensure the realization of her long term objective of improving the education sector. One of the provisions is to the enactment of Public Procurement Disposal Act in 2005.The main objectives of the Public Procurement Disposal Act (PPDA, 2005) are to maximize economy and efficiency; to promote competition and ensure that competitors are treated fairly; to promote the integrity and fairness of those procedures; to increase transparency and accountability in those procedures; and to increase public confidence in those procedures and to facilitate the promotion of local industry and economic development (Public Procurement and Disposal Act 2005).

Transparency is a means of fostering accountability, internal discipline, and better governance. Transparency and accountability improve the quality of decision-making in policymaking institutions as well as in institutions whose own decisions depend on understanding and predicting the future decisions of policy making institutions. The general public will be better able to monitor public sector institutions and therefore poor decisions will not go unnoticed or unquestioned. Transparency and accountability are mutually reinforcing. Transparency enhances accountability by facilitating monitoring also and accountability enhances transparency by providing an incentive for agents to ensure that the reasons for their actions are properly understood. Both transparency and accountability impose a discipline that improves the quality of decision-making in the public sector and lead to more efficiency in public sector (Greuning, 2005).

(Faircheallaigh et al. 1999:211) believes that transparency in decision making reduces the number of appeal cases. It allows aggrieved citizens to discover the formal reasons for a decision and if it is perceived to be flawed or unfair to challenge the decision. Transparency requires that governments not only prevent the flow of information to the public, but also be actively involvemed in making the necessary provisions to ensure public has information and can have a feedback effect on governmental activities since it 'empowers the public to put pressure on government to deliver services and to do so effectively. It can also enforce the legitimacy of government.

Looking at the indicators that attempt to evaluate government transparency, one can select, for instance, an indicator of administrative transparency, such as whether procedures for the procurement process are undertaken through a transparent and regulatory manner. Another indicator of transparency is the existence of an 
ombudsman office, which is fully staffed and funded and whether there are regular and independent financial audits of governmental and parastatal bodies. The above definition suggests that monitoring and auditing are crucial in transparency and public financial management. It is therefore imperative to monitor and audit procurement if it aims at achieving financial management which this research set out to do.

\section{Statement of the Problem}

Despite the important role played by the Procurement Act, it appears that government institutions in the Meru Region go through a lot of lengthy bureaucratic processes. Instead of the Act improving public financial management; it has rather weakened public financial management in the region. Some contractors and suppliers in the region have complained about lack of transparency in the procurement procedures and long delays in their payment after they have executed the project or supplied the goods. Poor procurement practices have led to accumulated interest on late payments and the frequent price changes due to extensive renegotiations which further exacerbate the funding act problem and have increased government expenditure and reduced savings (World Bank, 2003). There is also the issue that the passage of the procurement Act has increased government domestic debt management burden and reduced government investments according to (World Bank, 2003)

Unfortunately, no attempt has been made to assess the causes of delay in the implementation of the act, the effects of the act on government savings and expenditure and government debt burden as well as transparency in the use of state resources. The research therefore was an attempt to collect data to examine the causes of the delay, assess the effects of the act on government savings and expenditure (public financial management) as well as the effects of the act on transparency in the use of state resources and if the procurement process is fair and competitive.

\section{Purpose of the Study}

The purpose of the study of was to establish the effects of Public Procurement Disposal Act (2005) on transparency and accountability in the use of government financial resources.

\section{Research Questions}

The following research questions guided in achieving the objectives.

To what extent has the PPDA (2005) achieved transparency and accountability in the use of government financial resources?

Scope of the study.

According to Kombo and Tromp (2009) the scope of the study refers to the boundaries or limits within which the study needs to be kept. The reasons for such limits may be geographical, historical, ideological, person or any other. The scope of the study was limited to Imenti North District. The study targeted only public secondary schools in this district due to limited time and financial resources. The study only sought to investigate the effects of Public Procurement Disposal Act (2005) transparency and accountability in the use of public finance.

\section{Research Design}

In this study descriptive research design was employed. The major purpose of descriptive research is description of the state of affairs as it exists at present. In this case the research has no control over the variables. One will only report what is happening. It has also included attempts by researchers to discover causes even when they cannot control the variables. According to Mugenda and Mugenda (1990) the purpose of descriptive research is attempting "to describe such things as possible behaviors, altitudes, values, and characteristics. Target Population and Sample

The target population for the study included the principals and the persons in charge of procurement in public secondary school in Imenti North District. There are 54 public secondary schools in Imenti North District hence a population of 108 respondents.

A sample of 86 respondents was arrived at using a formula by Yamane, 1967. Using simple random sampling, the researcher sampled 43 public secondary schools in Imenti North District. Data Collection Instrument

Questionnaire was the main data collection instrument used in the study. The questionnaire was appropriate because it is assumed that the procurement officials were literate and for that matter they would be able to respond to the questions unaided. Questionnaire facilitated the collection of data and ensured the best matching of concepts with reality; it also provided the same responses from a given set of respondents and helps reduce inconvenience caused by unfavorable interview times and busy schedules.

\section{Data Processing and Analysis}

.Quantitative and qualitative methods was used to analyze the data. The results were computed into percentages and subsequently presented in the form of frequency tables. Computer data analyses software such as the use of Statistical Package for Social Sciences (SPSS) and other relevant software such as Microsoft Excel were the main tools employed to analyze the data in order to help interpret results. The open-ended were analyzed by listing all the important responses given by the respondents. The responses were considered based on the relevance to the study. This gave the general idea of the study with respect to the impact of the public procurement Act on financial management 


\section{Response Return Rate}

Table 1 indicates the response rate of the respondents. Out of 86 questionnaires distributed the respondents filled and returned all the questionnaires representing a response rate of $100 \%$.

Table 1: Response Return Rate

\begin{tabular}{|l|l|c|}
\hline Activity & $\begin{array}{l}\text { Frequency questionnaires } \\
\text { distributed }\end{array}$ & $\begin{array}{l}\text { Questionnaires } \\
\text { returned }\end{array}$ \\
\hline Men & 70 & 70 \\
\hline Women & 16 & 16 \\
\hline TOTAL POPULATION & $\mathbf{8 6}$ & $\mathbf{8 6}$ \\
\hline
\end{tabular}

Demographic Characteristics of the Respondents

The study sought to know the demographic characteristics of the respondents such as Number of years spent at work place, gender, marital status and age bracket

Distribution of respondents by number of years spent at work place.

The respondents were asked to state the number of years spent at the work place and the results are indicated in table 2

Table 2: Number of Years Spent at Work Place

\begin{tabular}{|l|l|c|}
\hline $\begin{array}{l}\text { No of years spent at } \\
\text { work place (Yrs) }\end{array}$ & frequency & Percentage \\
\hline $1-5$ & 34 & $39.5 \%$ \\
\hline $6-10$ & 44 & $51.2 \%$ \\
\hline $11-15$ & 5 & $5.8 \%$ \\
\hline $16-20$ & 3 & $3.5 \%$ \\
\hline Total & $\mathbf{8 6}$ & $\mathbf{1 0 0} \%$ \\
\hline
\end{tabular}

With regard to the number of years the respondents have spent at their work place $51.2 \%$ said that they had been at their work place for 6-10 years.39.5\% said that they had worked for 1-5 years while 5.8 \% said that they had worked for 11-15 years. The rest 3.5\% said that they had worked for 16-20 years.It is therefore evident that most of the respondents were more knowledgeable to answer the questionnaires.

Distribution of respondents by Gender

It was necessary to get information on the gender of the respondents so as to establish the percentage of each gender and therefore be able to make an inference from the information collected.

Table 3 Gender of the respondents

\begin{tabular}{|l|l|l|}
\hline Gender & frequency & Percentage \\
\hline Male & 70 & $81.4 \%$ \\
\hline Female & 16 & $18.6 \%$ \\
\hline Total & $\mathbf{8 6}$ & $\mathbf{1 0 0} \%$ \\
\hline
\end{tabular}

The findings of the research from table 3 shows that $81.4 \%$ were men who were procurement officers compared to women $18.6 \%$. This is a clear indication that men compose a large percentage of procurement officers in Imenti North District.

Distribution of respondents by marital status

The respondents were asked about their marital status and the results are indicated in table 4

Table 4: Marital status

\begin{tabular}{|l|l|c|}
\hline Marital status & frequency & Percentage \\
\hline Married & 75 & $87.2 \%$ \\
\hline Separated/divorced & 3 & $3.5 \%$ \\
\hline Widowed & 2 & $2.3 \%$ \\
\hline Single & 6 & $7.0 \%$ \\
\hline Total & $\mathbf{8 6}$ & $\mathbf{1 0 0} \%$ \\
\hline
\end{tabular}

The findings of this research on table 4 show that $87.2 \%$ of the respondents were married, $3.5 \%$ were separated/divorced, $2.3 \%$ were widowed and $7.0 \%$ were single. This therefore indicates that majority of the respondents were married.

Distribution of respondents by Age

It was also imperative to find out the age of the respondents so as to provide an insight into the area of the study and relate it to Public Procurement and Disposal Act (2005) on management of public finance and the results are indicated in table 5. 
Table 5: Age Bracket

\begin{tabular}{|l|l|l|}
\hline Age Bracket (yrs) & Frequency & Percentage \\
\hline Below 25 & 1 & $1.2 \%$ \\
\hline $26-35$ & 4 & $4.7 \%$ \\
\hline $36-45$ & 33 & $38.4 \%$ \\
\hline Over 46 & 48 & $55.8 \%$ \\
\hline Total & $\mathbf{2 2 0}$ & $\mathbf{1 0 0 \%}$ \\
\hline
\end{tabular}

The research also found that those respondents whose age was lying between 36-45 yrs were $38.4 \%$ and those between $26-35$ years were $4.7 \%$ as shown in table 4.5 . The respondents aged below 25 years were $1.2 \%$. Those over 46 years of age were $55.8 \%$.

Effects of Public Procurement and Disposal Act (2005) Transparency and Accountability on management of public finance

In order to establish if transparency and accountability had an impact on management of public finance it was imperative to assess transparency and accountability on the basis of: Availability of written records of procurement, Access to procurement information, Advertisement of contract, Tender invitation and opening, Methods of tendering, Appeal cases and resolution of disputes, Period for opening tendering and mode of opening and internal quality control

Effects of Public Procurement and Disposal Act (2005) Availability of written records of procurement.

The study sought to find out from the respondents whether they have written records of procurement and the results are indicated in the table below

Table 6: Availability of Written Records of Procurement

\begin{tabular}{|l|l|l|}
\hline $\begin{array}{l}\text { Availability of } \\
\text { written records }\end{array}$ & frequency & Percentage \\
\hline Yes & 69 & $80.2 \%$ \\
\hline No & 17 & $19.7 \%$ \\
\hline Total & $\mathbf{8 6}$ & $\mathbf{1 0 0} \%$ \\
\hline
\end{tabular}

Table 6 shows that that $80.2 \%$ of the respondents said that they had written record of procurement at their work place while the rest $19.7 \%$ indicated that they do not have written records of procurement at their work place.

Access to Procurement Information

The study also sought to know if the respondents published procurement information and the results are presented in figure below.

Table 7: Access to Procurement Information

\begin{tabular}{|l|l|c|}
\hline $\begin{array}{l}\text { Access to } \\
\text { procurement } \\
\text { information }\end{array}$ & Frequency & Percentage \\
\hline No & 74 & $86 \%$ \\
\hline Yes & 12 & $14 \%$ \\
\hline Total & $\mathbf{8 6}$ & $\mathbf{1 0 0} \%$ \\
\hline
\end{tabular}

From the findings of the research as shown in table 7 reveals that those who did not publish procurement information were $86 \%$ whereas those who published procurement information were $14 \%$. The reason given why they did not publish was due to lack of time and also the cost involved.

Effects of Public Procurement and Disposal Act (2005) Advertisement of contract and Medium of Advertisement

The respondents were asked how they advertised their contracts and the results are illustrated in the table below. Table 8: Advertisement of contract and Medium of Advertisement

\begin{tabular}{|l|l|l|}
\hline $\begin{array}{l}\text { Medium of } \\
\text { Advertisement }\end{array}$ & frequency & Percentage \\
\hline $\begin{array}{l}\text { National news } \\
\text { papers }\end{array}$ & 20 & $23.2 \%$ \\
\hline Internet & 3 & $3.5 \%$ \\
\hline Local radio & 60 & $69.8 \%$ \\
\hline Journal & 3 & $3.5 \%$ \\
\hline Total & $\mathbf{8 6}$ & $\mathbf{1 0 0} \%$ \\
\hline
\end{tabular}

The study results from table 8 revealed that majority of the respondents $69.8 \%$ advertised the contracts 
through local radio while $23.2 \%$ advertised through national newspaper. Those who admitted advertising the contracts using both the internet and the journals were similar at $3.5 \%$.

Effects of Public Procurement and Disposal Act (2005) Tender Invitation and Opening

The respondents were asked to state the minimum time period allowed for tender invitation and the results are indicated in table 9.

Table 9: Tender Invitation and Opening

\begin{tabular}{|l|l|l|}
\hline $\begin{array}{c}\text { Tender Invitation } \\
\text { and opening }\end{array}$ & frequency & Percentage \\
\hline Two weeks & 68 & $79.1 \%$ \\
\hline One month & 15 & $17.4 \%$ \\
\hline Two months & 2 & $2.3 \%$ \\
\hline $\begin{array}{l}\text { Three months and } \\
\text { above }\end{array}$ & 1 & $1.2 \%$ \\
\hline Total & $\mathbf{8 6}$ & $\mathbf{1 0 0 \%}$ \\
\hline
\end{tabular}

Results from table 9 revealed that $79.1 \%$ of the respondents said that they gave the bidders at least two weeks to submit their tenders while $17.4 \%$ said that they gave the bidders one month to submit their tenders.2.3 5\% said that they give them two months and the rest $1.2 \%$ said that they usually give them three months to have them submit their tenders.

\section{Methods of Tendering}

The respondents were asked if they made the right decision about their businesses whether it affected their performance and the results are indicated in table 10

Table 10: Methods of Tendering

\begin{tabular}{|l|l|l|}
\hline Methods of Tendering & frequency & Percentage \\
\hline Competitive tendering & 13 & $15.1 \%$ \\
\hline Selective tendering & 73 & $84.9 \%$ \\
\hline Total & $\mathbf{8 6}$ & $\mathbf{1 0 0} \%$ \\
\hline
\end{tabular}

Table 10 shows that $84.9 \%$ of the respondents said that the method they used for tendering was selective since they select individuals or companies to be awarded the tender on certain laid down criteria, while the rest $15.1 \%$ said that they used competitive tendering.

\section{Appeal cases and resolution of disputes}

The respondents were asked to state the about the appeal cases and resolution and the results are indicated in the table 11 below.

Table 11: Appeal Cases and Resolution of Disputes

\begin{tabular}{|l|l|l|}
\hline $\begin{array}{l}\text { Appeal cases } \\
\text { (annually) }\end{array}$ & frequency & Percentage \\
\hline One to five cases & 10 & $11.6 \%$ \\
\hline six to ten cases & 24 & $27.9 \%$ \\
\hline Ten and above & 52 & $60.5 \%$ \\
\hline Total & $\mathbf{8 6}$ & $\mathbf{1 0 0 \%}$ \\
\hline
\end{tabular}

The findings of this research showed that there was a significant number of ten and above appeal of $60.5 \%$ cases according to the respondents while $27.9 \%$ of the respondents said that there were six to ten appeal cases annually. The rest $11.6 \%$ said that there were only one to five appeal cases annually. $78 \%$ of the cases that were reported and in connection with procurement procedures were not resolved amicably. The rest $22 \%$ said that the appeal had not been resolved

Mode of opening Tenders

The respondents were asked to state the mode of opening tenders and the result are shown in table 12

Table 12: Mode of Opening Tenders

\begin{tabular}{|l|l|l|}
\hline $\begin{array}{l}\text { Mode of Opening } \\
\text { tenders }\end{array}$ & frequency & Percentage \\
\hline Publicly & 18 & $20.9 \%$ \\
\hline Privately & 68 & $79.1 \%$ \\
\hline Total & $\mathbf{8 6}$ & $\mathbf{1 0 0} \%$ \\
\hline
\end{tabular}

Results on table 12 indicate that $79.1 \%$ of the respondents agreed that the tenders were opened privately while the rest $20.9 \%$ said that they were opened publicly.

Internal Quality Control and Auditing of Procurement

The respondents were asked to state if there was internal quality control or auditing and their responses are shown in table 4.14 
Table 13: Internal Quality Control and Auditing of Procurement

\begin{tabular}{|l|l|l|}
\hline $\begin{array}{l}\text { Auditing of } \\
\text { Procurement }\end{array}$ & frequency & Percentage \\
\hline Yes & 40 & $46.5 \%$ \\
\hline No & 46 & $53.5 \%$ \\
\hline Total & $\mathbf{8 6}$ & $\mathbf{1 0 0 \%}$ \\
\hline
\end{tabular}

The researcher found that $53.5 \%$ of the respondents indicated that there was no auditing that was done of procurement while $46.5 \%$ said that auditing of procurement was done as indicated in table 13

Summary of the findings

\section{Effect of Public Procurement Disposal Act (2005) on Transparency and Accountability}

The study revealed that procurement entities have reliable and credible records of procurement activities. Record keeping enhances auditing, transparency and accountability in public financial management. Procurement Act stipulates that all procurement entities are to keep tangible records of procurement. It was also revealed that, the media through which the public gets to know the procurement advertisements or opportunities were the local radio with the highest percentage of $69.8 \%$ as compared with national newspaper of $23.2 \%$. This was not inconformity with the Procurement Act 2005 that requires procurement entity to publish tender invitation in a wide nationally circulated newspaper. The time allowed for tender invitation and opening was not manageable. Seventy nine per cent of the respondents acknowledged that the bidders were given only two weeks as maximum time period allowed for tender invitation and opening. Procurement entities thus did not allow enough periods for contractors to prepare for bidding. This step thus did not enhance procurement activities.

The Public Procurement Disposal Act (2005) is to obtain value for money hence save money. Most of the respondents said that they used selective tendering which may have resulted contractors/suppliers exercising monopolistic power with its associated problems of charging an exorbitant price for contracts.

The study found out that there were many appeal cases annually of more than ten. This meant that the many protests against procurement procedures by contractors were not amicably resolved. This meant procurement procedures were not transparent. Among the reasons assigned to the late payment upon completion of projects were that cash flows were irregular, bureaucracy, centralized payment system and political interference. Auditing is a crucial ingredient for a successful implementation of the Public Procurement Act. The study revealed that procurement entities had no quality control and auditing in their respective offices and their activities were not regularly audited to check arbitrary expenditure and achieve accountability

\section{Conclusion}

The Procurement Act has not brought transparency in the use of state resources since the study revealed that there is no openness and fairness in procurement activities in Meru. The Study also discovered that the decisions of procurement entities did not follow the rules and regulations of the Act and these decisions were not available and accessible to the public.

\section{REFERENCES}

Antill and Woodhead (1989).Factors influencing construction time and cost.Primavera system inc. Genome. Anvuur A. (2006).Taking Forward Public Procurement Reforms in Ghana. Hong Kong Unpublished MSc Thesis, Department of Civil Engineering, and University of Leeds.

Baily, P, Farmer, D, Jessop, D and Jones, D (1998).Purchasing Principles and M anagement; $8^{\text {th }}$ ed.Edinburgh: Prentice Hall

Björn Wickenberg (2004), Translation of Sustainability into Public Procurement Practices in Swedish Municipalities. Unpublished, MSc Thesis, Lund University.

Boone and Kurtz (1993). Contemporary Business, Dryden Press (Fort Worth)

Burke and Bittel (1991). Introduction to Management Practice, Macmillan/McGraw Hill, Columbus, Ohio

Chowdhury A. and Kirkpatrick C. (1994).Development Policy and Planning: An Introduction to Models and Techniques, London, Routledge.

Colander D. C, (2001) Economics, McGraw-Hill Companies. New York, US.

Coppens, O. (2009), Does Competition Save Taxpayer's Money in Public Procurement?

Estache, A. and A. Iimi (2008), "Benefits from Competition for Infrastructure Procurements and Financial Needs Reassessed," ECARES Conference on Emerging Competition Issues in the Procurement of Infrastructure Services,

Farmer, D and Weele, V (2000). Handbook of Purchasing M anagement; 2nd ed. Hampshire: Gowe Gareth (2000), Contemporary Management, McGraw-Hill Companies, U.S.

Gay, I. R. (1990). Educational research, competencies for analysis and applications. Merrill Publishing Company.

Griffin Ricky W. and Ebert Ronald J. (1999). Industrial Management, Prentice Hall. 
Grifith, M and Grifith, I (2002).Law of Purchasing and Supply; 3rd ed.Edinburgh: Prentice Hall.

Iimi, A. 2007, "Aid and Competition in Procurement Auctions: A Case of Highway Projects" Journal of International Development.

Janowitz (1977), Bureaucracy or Participation. Sega Publication, London, California.

Kipchilat, G.T (2006) “An Evaluation of the Impact of the Public Procurement Regulations on Procurement in Kenyan Public Universities.'Unpublished M BA Project. Egerton University.

Levacic and Rebmann (1982) Macroeconomics. Macmillan Ltd, London

Lovis E. Boone and David L.Kurtz ( 1993) Contemporary Business ( $7^{\text {th }}$ edition) Druden press, US

Malcolm G, el tal (1987) Economics of Development, Norton Company Inc. US, New York.

Marie Chêne (2009).The Political Economy of Public Procurement Reform, Transparency International

McConnell and Brue (2001) Microeconomics Principles, Problems and policies.McGraw Hill Companies. New York, US.

Ministry of Finance (2001) Procurement Reform Proposals. A component of the Public Financial Management Reform Programme.

Muriithi, N and Crawford, L (2003) Approaches to project management in Africa:implications for international development projects. International Journal of Project Management

Nickels (1999), Understanding Business ( $5^{\text {th }}$ ed), McGraw-Hill companies, U.S.NOU - the National Board for Public Procurement (2004)"A brief description of LOU - The Public Procurement Act in Sweden.

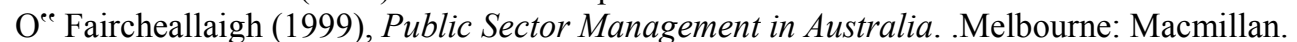

Ohio. Waara F. (2007), Mitigating Contractual Hazards in Public Procurement, A Study of Swedish Local

Authorities. Journal of Construction Management and Economics. Vol. 26,

Osafo-Marfo Y. (2003) Improving Efficiency and Transparency in PublicProcurement. Accra,Ghana

Pettinger, (2002) Introduction to Management. Palgrave, New York.

Prest A.R (1985), Public Finance in Developing Countries (3rd ed) Weidenfeld and Nicolson Limited, London.

Pride, Hughes and Kapoor (2002). The Environment of Business, Harvest Publishing.

Republic of Ghana, (2003). Role of Procurement and Legal Framework, Public Procurement Authority. Accra, Ghana.

Rose and Lawton, (1994).Improving Public Service Management, Pearson Education Limited.Harlow, England.

Rosse C. A el tal (2001).Essentials of Corporate Finance. McGraw-Hill Companies, US

Sarantakos, S. (1998). Social Research (2nd Ed.). London: MacMillan Press Ltd.

Saunders M el tal (2007), Research Methods for Business Students ( $7^{\text {th }}$ Edn), Pearson Education Limited. England, UK.

Tas, B K. O., Rasim Ozcan and Ilke Onur, 2008, "Public Procurement Auctions and Competition in Turkey",TOBB ETU..

Van Weele (2000).Purchasing and Supply Management, Thomson Press,

William M. Pride, Robert J. Hughes and Jack R. Kapoor (2002) Business. HoughtonMiffling Company, Boston,

New York.

Wind, Y and Thomas, R.J (2001). "The Buying Centre." European Journal of Marketing, available on http:/www.oecd.org, on 18thDec. 2012

World Bank (2001) Global Development Finance: Building Coalition for Effective Development Finance,

Washington DC

Yin, R. (1993) .Application of Case Study Research. Newbury Park, CA: Sage Publ 
The IISTE is a pioneer in the Open-Access hosting service and academic event management. The aim of the firm is Accelerating Global Knowledge Sharing.

More information about the firm can be found on the homepage:

http://www.iiste.org

\section{CALL FOR JOURNAL PAPERS}

There are more than 30 peer-reviewed academic journals hosted under the hosting platform.

Prospective authors of journals can find the submission instruction on the following page: http://www.iiste.org/journals/ All the journals articles are available online to the readers all over the world without financial, legal, or technical barriers other than those inseparable from gaining access to the internet itself. Paper version of the journals is also available upon request of readers and authors.

\section{MORE RESOURCES}

Book publication information: http://www.iiste.org/book/

\section{IISTE Knowledge Sharing Partners}

EBSCO, Index Copernicus, Ulrich's Periodicals Directory, JournalTOCS, PKP Open Archives Harvester, Bielefeld Academic Search Engine, Elektronische Zeitschriftenbibliothek EZB, Open J-Gate, OCLC WorldCat, Universe Digtial Library, NewJour, Google Scholar

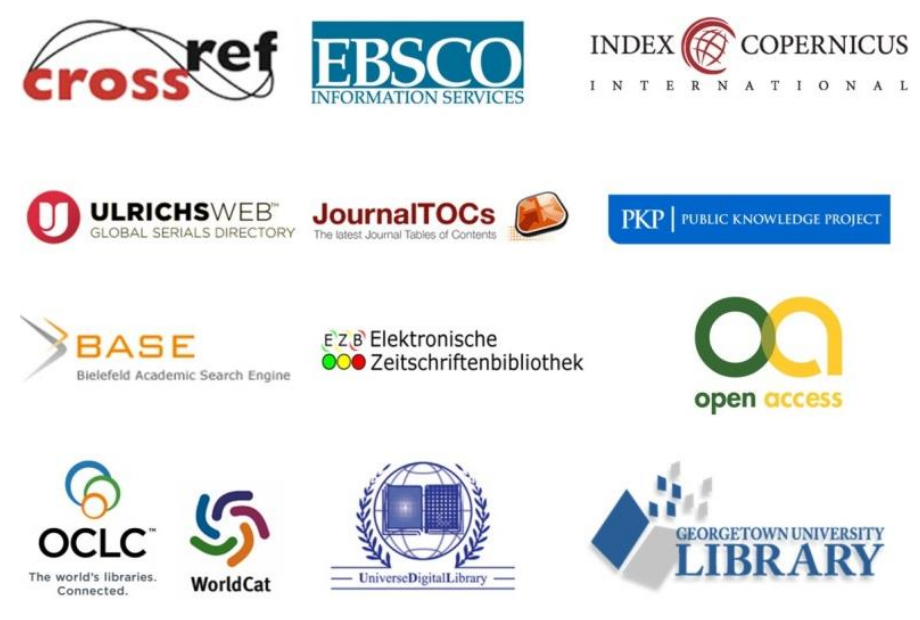

